\title{
Anticipation or risk aversion?: The effects of the EU enlargement on Korean trade and FDI activities in Central and Eastern Eu- rope *
}

Jong-Kun Jun, Jae Hoon Hyun ${ }^{* *}$

This study attempted to identify how regional integration and spatial enlargement would affect firms' strategic decisions from the outside of an integrated region. By analyzing data sets between 2000 and 2007 utilizing the gravity model, this study examined the specific properties of Korean trade and FDI flows to the participating 5 CEECs and 5 western European states before and after the enlargement of the EU. The initial findings show that the number of new investments increased significantly after the enlargement while the monetary amount of total investment appeared to be negligibly affected. Further examinations by firm size revealed that SMEs were responsible for increased Korea FDI after the enlargement while large companies did not make any contributions. Having different attitudes toward risk aversion and anticipating opportunities for exploitation were suggested as a possible explanation.

Diese Studie versucht zu ermitteln, wie die regionale Integration und die räumliche Vergrößerung die strategischen Entscheidungen der Unternehmen außerhalb einer integrierten Region beeinflussen. Mittels Analyse von Datensätzen zwischen 2000 und 2007 werden die spezifischen Eigenschaften des koreanischen Handels und die FDI-Ströme zu den beteiligten 5 MOEL und 5 westeuropäischen Staaten vor und nach der Erweiterung der EU untersucht. Die anfänglichen Ergebnisse zeigen, dass die Anzahl der neuen Investments nach der Erweiterung deutlich gestiegen ist, wohingegen die monetäre Menge der Gesamtinvestitionen nur unwesentlich beeinflusst schien. Weitere Untersuchungen mit Blick auf die Unternehmensgröße zeigten, dass die KMUs für die Erhöhung der Koreanischen FDI nach der Erweiterung verantwortlich waren, während große Unternehmen keine Beiträge geleistet haben. Unterschiedlichen Einstellungen gegenüber Risikoaversion und das Erahnen von Verwertungsmöglichkeiten sind mögliche Erklärung dafür.

Keywords: EU, CEEC, enlargement, Korea, FDI, SME (JEL: F21, N23)

\footnotetext{
* Manuscript received: 31.05 .13 , accepted: 31.01 .14 (2 revisions)

** Jong-Kun Jun, Professor, Department of International Business, Hankuk University of Foreign Studies, Korea. Main research interests: FDI, international marketing, SME's marketing. E-mail: jkjun@hufs.ac.kr

Jae Hoon Hyun, Associate Professor, Department of International Business, Hankuk University of Foreign Studies, Korea. Main research interests: economic integration, FDI, automobile industry, international strategic alliances, collaborative innovation. E-mail: jhyun@hufs.ac.kr (corresponding author)
} 


\section{Introduction}

The development of regionalism in Europe has posed threats as well as opportunities for firms from foreign countries. They have been required to tune their strategies in order to access the European markets and sustain trade flows, and in many cases, have been compelled to produce locally in the substitution of trade (Hirsh/Almor 1995). In particular, the trade and investment environment in Europe has been transformed dramatically since 2004, when the 6 CEECs (Central and Eastern European countries) joined the EU. Political impetus provoked rapid development of the business environment in various dimensions, such as liberalized trade regime, extensive privatization and improved legal and regulatory framework as well as opportunities to test the applicability of existing theories in international business and management (Meyer and Peng, 2005; Alguacil et al, 2008). The expected impact of enlargement does not come at the expense of external countries and is mutually beneficial for insiders and third countries alike and the sustainable development of foreign firms in Europe has been proposed to be dependent on the strategic alignment of external firms (Barrell/ Holland 2000; Pelkman/Casey 2003).

This study evaluates the transition of FDI and the export of Korean firms to newly joined member states in search of the effects of the enlargement of the EU in 2004 on the business activities of firms from external countries. Since the 1990s, Korean FDI headed towards developing countries for labor-intensive sectors, and the automobile and electronics sectors targeted U.S. and European countries to evade tariff and non-tariff barriers (Sachwald 2001). In particular, FDI flows to developed countries are unlikely to be explained by cost dimensions or firm-specific advantages (Freund/Simeon 2000). This study focuses on this aspect, and considers regional economic integration as a significant factor that accelerates complementarities between FDI and trade. Previous studies related to this subject have focused principally on the mutual FDI flows between and among regions, and only few studies have been conducted regarding the effects of enlargement on trade and investment, particularly from external countries (Pelkmans/Casey 2003).

By examining the various dimensions of trade and inward FDI properties before and after the enlargement from Korean companies, we hope to address how firms from external countries recognized and reacted to the enlargement of the EU. The objective of this study is embodied in the following research questions. First, how have trade and investment flows have changed before and after the enlargement and did the enlargement contribute as an effective variable to those changes? Did it show different patterns of capital flows between the 15 member states of CEECs and the EU? Second, has trade been substituted by FDI inflows or do they have complementary relations? Last but not least, what are the specific properties of Korean FDI before and after the enlargement by number, amount, time of FDI and the size of investing firms? An elaborate analysis, as a 
component of this research endeavor, may provide a thorough understanding of how regional integration and territorial enlargement would affect the strategic decisions of different types of firms from outside of an integrated region.

This study employs investment data compiled between 2000 and 2007 in order to assess any significant transitions in trade and FDI inflows prior to and after the enlargement event. In particular, the patterns and transition of Korean trade and FDI are compared among different groups of Korean firms divided by the their size in order to identify the particular character of Korean FDIs and how the enlargement is interpreted and responds differently according to the conditions of different groups of firms. The scope of this study extends to the unilateral trade and FDI flows from Korea to certain CEECs and major western European countries. This study is structured as follows: theoretical background, methodology, data and our results of analysis followed by a discussion and conclusion.

\section{Literature review and hypotheses development}

\section{$2.1 \quad$ Enlargement and FDI}

Enlargement of the EU may be considered to be a part of the important progresses of the economic integration in Europe. The practical linkage between the progress of economic integration and the changes of FDI flows are considered to be intertwined, in that regional integration increases preference for local production within the area (Dent 1997; Benton et al. 1999; Buckley et al. 2001). It was suggested that degree of integration and institutional development achieved among the transition countries in Europe induced a greater capacity in the attraction of FDI flows and affected entry mode choice multinational enterprises (Meyer 2001; Altomonte/Guagliano 2003).

From a theoretical point of view, the traditional variables of the locational determinants of FDI, as put forth in the corporate investment theory, suggest that the size of the host market, growth of the host market, factor prices and potential are all related to the static and dynamic effects of economic integration (Brenton 1999). A sizable market without boundaries enables local firms to realize economies of scale; thus, efficiency and competitiveness within the region should be enhanced (Balassa 1961; Corden 1972; European Commission 1997). Market expansion, demand-led growth and technical progress induce neutral or negative trade increases, whereas offensive export substitution investments to local-based affiliates increase accumulative FDI inflows (Nielsen et al. 1992; UNCTC 1990; Yannopoulos 1990). A number of empirical studies, including Scaperlanda and Mauer (1969; 1973), examined the U.S. FDI in the EC by evaluating market size, growth and tariff barriers variables, concluding that market size affects U.S. FDI inflows significantly. 
The theory of international production and customs unions suggests that, in response to trade diversion, multinationals tend to assume a defensive position and shift production to the customs union (Viner 1950; Nielson et al. 1992; UNCTC 1990; Yannopoulos 1990). Investment diversion owing to the magnetic effects of economic integration may adversely affect developing countries; however, when developing countries are included in the economic integration, they will tend to be perceived as the possible locations for FDI (UNCTC 1990). In addition, fears of a 'Fortress Europe' triggered by trade restrictions have been identified as a significant variable for the majority of U.S. FDI in the 1950s and 1960s (Clegg 1999), Japanese FDI in the 1980s and 1990s (Buigues/Jacquemin 1994), and other inward FDI to the EC, as compared to other regions (Dunning 1997).

Based on the above theoretical considerations, firms from the outside may exploit opportunities to service these markets and may defend their existing market share by means of local production which consequently results in the increased level of FDI inflows. However, in order to isolate the effect of enlargement, it is necessary to ask specific questions of industrial location of FDI. The determinants of inward FDI to CEECs, even prior to enlargement, are factored by large domestic markets, close proximity to western Europe, low wages and other production costs, plentiful natural resources, and in which state-owned enterprises have been privatized (UNCTC 1994; Lankes/Venables 1996; Resmini 2000; Bevan et al. 2001; Rutkowski 2006). The EU membership of CEECs and subsequently reduced uncertainty therefore appear to have provided a definitive edge over other states in attracting FDI for export platform-types of offshore production (Hirsch/Almor 1995; Kumar 1998; Barry 2002; Carstensen/Toubal 2003; Tintin 2013). The significant determinants of FDI in CEECs during 2000s such as the high $\mathrm{R} \& \mathrm{D}$ intensity, low country risk, large economic size and high growth, international experience, and market confirming values were derived by the accession to the EU (Janicki/Wunnava 2004; Larimo/Arslan 2013). In fact, the actual FDI inflows to the CEECs showed a dramatic increase in the early 2000 and continued through the mid-2000, coinciding with the event of the enlargement of the EU (Galego et al. 2004; UNCTAD 2009).

Alguacil et al. (2008) investigated FDI inflows to the CEECs and EU-15 and suggested that nature of capital flows are different between two regions affected by the enlargement. In particular, it was pointed out that business stabilizes within the Euro-area after the enlargement, the potential of market integration of CEECs was higher with distant industrialized countries and emerging economies than those in the Euro-area (Baldwin et al. 1997; Bussière 2008). Therefore, the number and amount of inflow FDI to the major EU countries after the enlargement would decrease or stabilize as the CEECs may significantly substitute potential FDI flows to the Euro-area (Eckert/Rossmeissl 2005). Hence, this study suggests the following hypotheses; 
Hypothesis 1a: The number and amount of inward FDIs to the CEECs from Korea would be positively affected by the realization of EU enlargement.

Hypothesis 1b: FDI inflows to major EU countries after the enlargement would be stabilized or decreased, as those to the CEECs would have substituted Korean FDI to the other Euro regions.

\subsection{Trade and FDI flows}

The effects of enlargement on trade and FDI flows in the EU were considered to be of particular interest because the widening membership may result in diversity that harms the deepening of the integration process (Marques 2008; Skinner et al. 2008). Related to external economies, it is necessary to ask a question as to whether increased FDI inflows are at the expense of trade to the EU and the passive reaction of external firms to the fortress Europe thesis.

In the traditional trade model, FDI and trade were substitutable because firms replace traditional trade in finished goods with FDI activities, such as sales by their foreign affiliates, internalization and direct involvement in arm's length trade (UNCTAD 1996; Markusen 1995; Brenton/Di Mauro 1999). The neoclassical approach also suggested that trade in goods was seen as a substitute of trade in the factors, where exporting countries are those with lower production prices, implying that lower factor returns provide an incentive for factors to flow to the importing country (Viner 1950).

Nevertheless, the approach of the new economic geography suggests that goods and factors tend to a complement that exporting countries have a cost advantage but higher real factor returns which provide an incentive for factors to flow to the exporting country due to imperfect competition and transport costs (Krugman 1991). In particular, the emergence of intra-firm trade by MNEs and vertical and horizontal integration within and across the industries nevertheless extended the scope of the trade model, embracing the complementarities between FDI and trade (Buckley/Casson 1981; Brainard 1993, 1997; Helpman 1984).

Lipsey and Weiss (1984), and Rugman (1990) also asserted that effective supply chain management and services by means of local production would increase the overall demand for particular products. A positive correlation between the expansion of U.S. FDI and the expansion of its trade was identified empirically (Bergsten et al. 1978). It has also been argued that the level of production by U.S. subsidiaries in a host country exerts a positive impact on U.S. exports and patterns of FDI were closely related to trade flows (Lipsey/Weiss 1981; Lansbury et al. 1996). Carstensen and Toubal (2003) examined the determinants of FDI into the CEECs concluded that FDI and trade are complementary from the negative impact of trade costs on FDI. This study therefore supports the complemen- 
tarities of trade and FDI flow in diverse EU thesis and suggests the following hypothesis;

Hypothesis 2: Korean FDI inflows and trade volume to the CEECs would have been complementary, and increased FDI flows are not at the expense of trade to the CEECs as a whole.

\subsection{Motives of FDI to an enlarged Europe: anticipation or risk aversion?}

Brenton and Di Mauro (1999) suggested that FDI in CEECs was greater than what one should expect, given the actual level of income, market size and psychic proximity which implied the effect of enlargement. The study on the impact analysing the prospective investment flows between the UK and six CEECSs even indicated that there were no significant enlargement impact (Görg/Greenaway 2003). In order to combine those controversial points of views, it is necessary to understand the effects of enlargement before and after the actual accession of member states. The study on EU enlargement and trade integration showed that the actual accession to the EU and trade integration within the region have a significant scope as the pace of integration slows down (Eckert/Rossmeissl 2005; Bussiere 2008). Egger and Phaffermayr (2004) have suggested that integration effects on FDI relations in Europe have been principally anticipatory in nature. The results of their study revealed that anticipation effects on FDI typically take place between the announcement and the formal establishment of an integration event, and the integration effects appear to be exhausted with formal completion (Bevan/Estrin 2004; Galego et al. 2004).

One of the negative consequences of larger Europe that motivates external firms even before the actual accession of the CEECs is protectionism. According to the propositions of a quid pro quo FDI, a firm may decide to invest in order to defuse the expected protection or threats even prior to the actual imposition of protectionist measures. This is particularly applicable to any pre-emptive moves by third-country firms with innate constraints, owing to the smallness of and sensitivity to the negative effects of political and economic integration (Hirsch/ Almor 1995; Eckert/Rossmeiss1 2005). In association with the defensive motivations of FDI, a quid pro quo FDI or tariff-threat defusing FDI should be differentiated from defensive import substituting FDI, as this is regarded as a structural advance to prevent future trade restrictions (Bhagwati 1983; 1987).

Cieslik and Ryan (2004) suggested that the official entry into the EU for the majority of CEECs was expected to be insignificant for Japanese FDI into these countries because it had already been factored into the investment equation, even before their entry. In the case of Korean automotive FDI in Europe, it was primarily a pre-emptive strategic reaction to the expected imposition of protectionist measures on Korean imports as a negative consequence of economic integration, which was not actually realized (Hyun 2003). 
It is therefore plausible that the actual time of FDI from external firms and the event of enlargement would show lags as firms may be motivated by the expected effects and consequences of the enlargement. Related to the specific motives and time of FDI, we also assume that different types of firms and resource availabilities might have affected the FDI patterns. It is assumed that larger firms with abound resources invested before the actual enlargement with the motive to exploit opportunities and pre-empt others, whereas investment after the enlargement are responsible for small- and medium-sized firms with a lack of resources attempting to avoid risks and uncertainties associated with the enlargement (Eckert/Rossmeissl 2005). Incorporating anticipatory and risk aversion aspects of Korean FDI, this study suggests the following hypothesis;

Hypothesis 3: Korea FDI in the CEECs after the enlargement would be responsible for SMEs in order to avoid risks and uncertainties as larger firms would have completed the anticipatory investment before the actual accession of the new member states.

\section{Research method}

Gravity models have frequently been utilized to explain bilateral trade, including FDI flows. A number of studies examining the key determinants of trade and FDI flows in CEECs, such as country risk, labor cost and country size also employed gravity factors (Bevan/Estrin 2004; Papazoglou et al. 2006). This study therefore adopted general variables of the gravity model, such as GDP and population and we added the dummy variable of the EU membership of the CEECs, such as the Czech Republic, Romania, Poland, Hungary and Slovak Republic, as this study focuses primarily on the transition of FDI flows from Korea to these countries following the accession to the EU.

It is also appropriate to apply the Poisson regression model rather than OLS regression because FDI cases are count data. The expected number of events within the specific length of time can be described as $E\left(y_{i} l x_{i}\right)=e^{\beta^{\prime}} x_{i}$, which is exhibited in the log-linear model as formula (1).

$\operatorname{lnE}\left(\mathrm{FDI}_{\text {Cases }_{\mathrm{t}}}\right)=\alpha+\beta_{1} \mathrm{EU}_{\mathrm{t}}+\beta_{2} \ln \left(\mathrm{GDP}_{\mathrm{t}} / \mathrm{POP}_{\mathrm{t}}\right)+\beta_{3} \ln \left(\mathrm{POP}_{\mathrm{t}}\right)+\beta_{4} \ln \left(\right.$ Other $\left._{\text {Cases }_{\mathrm{t}}}\right)+\varepsilon_{\mathrm{t}}$

In order to test the variables affecting monetary FDI, an OLS regression model has been adopted and applied in the logarithms for variance stability (2).

$\ln \left(\mathrm{FDI}_{\text {Monetary }_{\mathrm{t}}}\right)=\alpha+\beta_{1} \mathrm{EU}_{\mathrm{t}}+\beta_{2} \ln \left(\mathrm{GDP}_{\mathrm{t}} / \mathrm{POP}_{\mathrm{t}}\right)+\beta_{3} \ln \left(\mathrm{POP}_{\mathrm{t}}\right)+$ $\beta_{4} \ln \left(\right.$ Other $\left._{\text {Monetary }}\right)+\varepsilon_{\mathrm{t}}$ 
The relationship between FDI and export of Korean companies in the five Eastern European countries before and after their EU membership can be measured using the following regression model (3).

$$
\ln \left(\text { Export }_{\mathrm{t}}\right)=\alpha+\beta_{1} \mathrm{EU}_{\mathrm{t}}+\beta_{2} \ln \left(\mathrm{GDP}_{\mathrm{t}} / \mathrm{POP}_{\mathrm{t}}\right)+\beta_{3} \ln \left(\mathrm{POP}_{\mathrm{t}}\right)+\beta_{4} \ln \left(\mathrm{FDI}_{\text {Monetary }}\right)+\varepsilon_{\mathrm{t}}
$$

$\mathrm{FDI}_{\text {Cases }}$ is the number of new investments to the 5 Eastern European countries by Korean firms in year t. $\mathrm{FDI}_{\text {Monetary }_{\mathrm{t}}}$ denotes the monetary amount of total investments to the 5 Eastern European countries by Korean firms in year $\mathrm{t}$.

POP refers to a country's population, basically a measurement of country size, and (GDP/POP) is the real gross domestic product per capita, which is a measure of capital abundance.

According to previous studies, we anticipate more FDI flows to countries with high populations and GDP per capita figures. The $\mathrm{EU}_{\mathrm{t}}$ is a dummy variable that is coded as 0 if the variable year was before the accession, and 1 for the following years. We coded 0 between 2000 and 2003 for 4 countries that joined in 2004 and 1 that joined between 2004 and 2007, with the exception of Romania, which joined the EU in 2007. Owing to the limitations in the available data, we excluded the anticipatory effects of the EU enlargement from our empirical models.

Other $_{\text {Cases }}$ and Other Monetary $_{t}$ represent covariates that are calculated as the differences between total Korean FDI and Korean FDI in the CEECs in year t. In order to examine the changes of Korean FDI in Europe after the enlargement of the EU, it is necessary to isolate FDI in the CEECs from the general tendency of Korean FDI to the world during the same period. By incorporating these variables to the formula, we may segregate the increasing trends of Korean FDI to the world, which resulted from the overall globalization of Korean firms.

The majority of data, including the number of new investments, the money amount of total investment, and exports were collected from the database of The Export-Import Bank of Korea. Data related to FDI provide in-depth figures by industry and by year. In the case of Korea, it is mandatory for Korean firms to register all FDI they make; thus, the data reflect real cases and amounts of FDI.

We limited the number of countries to 5 countries - the Czech Republic, Romania, Poland, Hungary and the Slovak Republic. These countries consisted of more than $95 \%$ of total Korean FDI headed for the CEECs between 2000 and 2005. The population and GDP information of the 5 countries in the CEECs were gathered via Eurostat (http://epp.eurostat.ec.europa.eu). The data cover 8 years from 2000 to 2007. The same data from five Western European countries, including Germany, France, U.K., Spain and Italy, were collected for a compari- 
son. According to The Export-Import Bank of Korea, the investment of Korean firms to the five CEECs mounted up to 1,470 million U.S. dollars in 141 cases.

\section{Results}

Table 1 shows the results of the analysis for both baseline models, including and excluding the EU membership of the five CEECs as the variable by applying the Poisson regression for FDI cases and OLS regression for monetary FDI. The maximum VIF value was 2.6, indicating that the model is free from multi-collinearity problem.

Table 1: Regression results on five Eastern Europe countries: number of new FDI

\begin{tabular}{|c|c|c|c|c|}
\hline & \multicolumn{2}{|c|}{$\begin{array}{c}\text { Poisson Regression } \\
\text { (Dependent: FDI Cases) }\end{array}$} & \multicolumn{2}{|c|}{$\begin{array}{c}\text { OLS Regression } \\
\text { (Dependent: Monetary FDI) }\end{array}$} \\
\hline & Our Model & $\begin{array}{c}\text { Baseline } \\
\text { Model }\end{array}$ & Our Model & $\begin{array}{c}\text { Baseline } \\
\text { Model }\end{array}$ \\
\hline Constant & $\begin{array}{c}-16.325 * * \\
(4.561)\end{array}$ & $\begin{array}{c}-26.467 * * \\
(3.302)\end{array}$ & $\begin{array}{l}-20.195 \\
(14.125)\end{array}$ & $\begin{array}{l}-23.310 \\
(11.725)\end{array}$ \\
\hline EU (after=1) & $0.930 * *(0.308)$ & & $0.323(0.785)$ & \\
\hline $\begin{array}{l}\log \text { of GDP } \\
\text { per capita }\end{array}$ & $\begin{array}{c}0.276 \\
(0.307)\end{array}$ & $\begin{array}{c}0.709 * * \\
(0.264)\end{array}$ & $\begin{array}{l}2.673 * * \\
(0.877)\end{array}$ & $\begin{array}{l}2.827 * * \\
(0.780)\end{array}$ \\
\hline $\log$ of population & $\begin{array}{c}0.143 \\
(0.115)\end{array}$ & $0.177(0.118)$ & $0.320(0.424)$ & $0.309(0.417)$ \\
\hline $\begin{array}{l}\log \text { of other } \\
\text { FDI cases }\end{array}$ & $\begin{array}{l}1.630 * * \\
(0.396)\end{array}$ & $\begin{array}{l}2.286 * * \\
(0.306)\end{array}$ & & \\
\hline $\begin{array}{c}\log \text { of other } \\
\text { monetary FDI }\end{array}$ & & & $0.093(0.630)$ & $0.227(0.530)$ \\
\hline $\begin{array}{c}\text { Pearson Chi-square } \\
\text { (df) }\end{array}$ & $90.563(35)$ & $103.668(36)$ & & \\
\hline Log Likelihood & -100.220 & -105.003 & na & na \\
\hline $\mathrm{R}$ square & na & na & 0.468 & 0.464 \\
\hline
\end{tabular}

$* \mathrm{p}<0.05, * * \mathrm{p}<0.01,()$ standard error

The results of the regression analysis indicated that the number of new investments of Korean firms in the 5 CEECs after the accession of the EU indicated increased significance (beta $=0.930, p<0.01$ ). The likelihood ratio test statistic for the variable of EU accession led to the same conclusion. However, there was a change in the monetary investment after the EU membership turned out to be insignificant; thus, H1a was partially supported. The number of investments increased after the EU membership, whereas the monetary investment was insignificantly affected. Considering that the size of each investment is comparatively 
insignificant, it is plausible that small and medium enterprises would have mobilized the majority of investments after the EU enlargement while large companies were focusing on the sequential investment. GDP per capita has a positive relationship with the money amount of total investments (beta $=2.673, \mathrm{p}<0.01$ ), which is in accordance with previous researches using the gravity model, whereas the impact of population was not significant. The results reveal Korean companies' preference for relatively advanced economies among the CEECs.

Table 2 shows the results of the same analysis in Table 1 in five Western European countries. We applied the basis year for the dummy variable of the EU enlargement as 2004 because four out of five CEECs countries in our data joined this year, except for Romania which joined in 2007. The maximum VIF value was 2.8 , indicating that multicollinearity is not a problem in this model. The results revealed that both the cases and amounts of FDIs of Korean firms in the five Western European countries were not influenced by EU accession of the five CEECs, which supports $\mathrm{H} 1 \mathrm{~b}$.

Table 2: Regression results on five Western Europe countries: number of new FDI

\begin{tabular}{|c|c|c|c|c|}
\hline & \multicolumn{2}{|c|}{$\begin{array}{c}\text { Poisson Regression } \\
\text { (Dependent: FDI Cases) }\end{array}$} & \multicolumn{2}{|c|}{$\begin{array}{c}\text { OLS Regression } \\
\text { (Dependent: Monetary FDI) }\end{array}$} \\
\hline & Our Model & $\begin{array}{c}\text { Baseline } \\
\text { Model }\end{array}$ & Our Model & $\begin{array}{c}\text { Baseline } \\
\text { Model }\end{array}$ \\
\hline Constant & $\begin{array}{l}-85.825^{* *} \\
(8.221)\end{array}$ & $\begin{array}{c}-87.479 * * \\
(7.843)\end{array}$ & $\begin{array}{c}-67.304 * * \\
(26.415)\end{array}$ & $\begin{array}{l}-74.263 * * \\
(24.572)\end{array}$ \\
\hline $\mathrm{EU}($ after $=1)$ & $\begin{array}{c}0.201 \\
(0.286)\end{array}$ & & $0.639(0.854)$ & \\
\hline $\begin{array}{l}\log \text { of GDP } \\
\text { per capita }\end{array}$ & $\begin{array}{l}4.539 * * \\
(0.695)\end{array}$ & $\begin{array}{c}4.477 * * \\
(0.687)\end{array}$ & $\begin{array}{l}8.200 * * \\
(2.817)\end{array}$ & $\begin{array}{l}8.657 * * \\
(2.733)\end{array}$ \\
\hline log of population & $\begin{array}{l}2.526^{* *} \\
(0.320)\end{array}$ & $\begin{array}{l}0.532 * * \\
(0.320)\end{array}$ & $0.807(1.988)$ & 0.603 (1.957) \\
\hline $\begin{array}{l}\text { log of other } \\
\text { FDI cases }\end{array}$ & $\begin{array}{l}-0.429 \\
(0.407)\end{array}$ & $\begin{array}{l}-0.172 \\
(0.182)\end{array}$ & & \\
\hline $\begin{array}{l}\log \text { of other } \\
\text { monetary FDI }\end{array}$ & & & $-1.306(0.819)$ & $-0.905(0.616)$ \\
\hline $\begin{array}{c}\text { Pearson Chi-square } \\
\text { (df) }\end{array}$ & $45.710(35)$ & $46.323(36)$ & & \\
\hline Log Likelihood & -95.181 & -93.428 & na & na \\
\hline R square & na & na & 0.432 & 0.423 \\
\hline
\end{tabular}

$* \mathrm{p}<0.05, * * \mathrm{p}<0.01$, () standard error 
The OLS regression results in Table 3 reveal that Korean exports to the five CEECs significantly increased after the EU accession, which supports H2. The inward FDI in the CEECs may cause the increase of imports due to the high demand of intermediate goods, such as parts and components when the competitiveness of foreign firms on the domestic market has enhanced (Vavilof 2005). According to our result, the monetary FDI into CEECs from Korea did not have a significant relationship with Korean exports into the same region.

Table 3: Regression results on Korean Exports to the five CEECs

\begin{tabular}{|c|c|c|}
\hline \multirow{2}{*}{} & \multicolumn{2}{|c|}{$\begin{array}{c}\text { OLS Regression } \\
\text { (Dependent: Export) }\end{array}$} \\
\cline { 2 - 3 } & Our Model & Baseline Model \\
\hline Constant & $1.562(4.783)$ & $-3.931(5.589)$ \\
\hline EU (after=1) & $0.972^{* *}(0.258)$ & $1.086^{*}(0.424)$ \\
\hline log of GDP per capita & $0.416(0.389)$ & $0.376(0.200)$ \\
\hline log of population & $0.386^{*}(0.163)$ & $0.149(0.093)$ \\
\hline $\log$ of monetary FDI & $0.116(0.076)$ & 0.496 \\
\hline R square & 0.678 & \\
\hline
\end{tabular}

$* \mathrm{p}<0.05, * * \mathrm{p}<0.01$, () standard error

The Poisson regression results for the two groups of different company sizes showed that the EU accession of the five CEECs was positively related to the number of investments initiated by SMEs of Korea (beta=1.062, $\mathrm{p}<0.05$ ) (see Table 4). However, the EU accession had no relationship with the FDIs of large Korean companies in the region. This result supports our argument in H3, that Korean SMEs increased the number of new investments to the CEECs after the EU membership in order to averse the investment risk associated with the uncertainties of the EU enlargement.

Similarly, the monetary FDI of Korean SMEs into the CEECs was significantly increased after the EU accession of the five countries (beta $=3.887, \mathrm{p}<0.01$ ), whereas the investment of large companies was not increased. This result also confirms our proposition in H3. The investment of large companies was related with GDP per capita and population. 
Table 4: Results by company size

\begin{tabular}{|c|c|c|c|c|}
\hline & \multicolumn{2}{|c|}{$\begin{array}{c}\text { Poisson Regression } \\
\text { (Dependent: FDI Cases) }\end{array}$} & \multicolumn{2}{|c|}{$\begin{array}{c}\text { OLS Regression } \\
\text { (Dependent: Monetary FDI) }\end{array}$} \\
\hline & $\begin{array}{c}\text { Large } \\
\text { Companies }\end{array}$ & SMEs & $\begin{array}{c}\text { Large } \\
\text { Companies }\end{array}$ & SMEs \\
\hline Constant & $-9.549(8.112)$ & $\begin{array}{c}-18.224^{* *} \\
(6.165)\end{array}$ & $\begin{array}{l}-94.977 * \\
(39.508)\end{array}$ & $\begin{array}{l}-62.559^{*} \\
(24.458)\end{array}$ \\
\hline EU (after $=1)$ & $0.910(0.551)$ & $1.062 *(0.432)$ & $0.691(2.296)$ & $\begin{array}{l}3.887 * * \\
(1.422)\end{array}$ \\
\hline log of GDP per capita & $0.615(0.518)$ & $0.038(0.427)$ & $4.943 *(2.140)$ & $0.668(1.325)$ \\
\hline $\log$ of population & $0.208(0.207)$ & $-0.031(0.155)$ & $2.797 *(1.128)$ & $1.507 *(0.698)$ \\
\hline $\log$ of other FDI cases & $0.185(0.722)$ & $\begin{array}{c}2.379 * * \\
(0.559)\end{array}$ & & \\
\hline $\begin{array}{l}\log \text { of other } \\
\text { monetary FDI }\end{array}$ & & & $0.793(1.953)$ & $2.270(1.209)$ \\
\hline $\begin{array}{c}\text { Pearson Chi-square } \\
\text { (df) }\end{array}$ & $48.932(35)$ & $65.730(35)$ & & \\
\hline Log Likelihood & -61.593 & -70.667 & na & na \\
\hline $\mathrm{R}$ square & na & na & 0.315 & 0.596 \\
\hline
\end{tabular}

$* \mathrm{p}<0.05, * * \mathrm{p}<0.01$, ( ) standard error

\section{Discussion and implications}

This study examined the overall effects of the enlargement of the EU on the trade and FDI flows from Korea. In particular, the focus has been given to the substitution of regional FDI inflows and complementarity between trade and FDI after the enlargement. The findings and the results of the hypotheses test showed us that FDI inflows from Korea had been significantly influenced by the changes in Europe. Other gravity factors, such as GDP and population, were not decisive variables affecting the FDI flows as much as we expect. Trade and FDI were not substitutive and trade flows to Europe from Korea after the enlargement were even increased. In addition, FDI inflows to the CEECs were not at the expense of flows to the Western European states and this result coincided with the previous study asserting that FDI going to the CEECs did not have a negative impact upon the flows of overseas investment going to other European countries (Brenton et al. 1999). This result indicates that the enlargement itself is a valid and independent factor affecting the FDI flows, and Korean firms consider this variable as being significant when they make investment decisions regarding Europe, particularly the CEECs.

The particular result that drew our attention was that as the number of FDI were clearly increased after the enlargement, the monetary amount of FDI was not 
found to be significantly affected. This result provided an idea that the scale of FDI to the CEECs after 2004 was comparatively diminutive. We assumed that the characteristics of these FDI might be resulted from the different investment behaviors between large firms and SMEs with limited financial resources. If this should be the case, we considered that the main motivation and characteristics of FDI carried out by SMEs are to avert risks and uncertainties derived from the enlargement of the EU. Larger firms with the capacity and capability to cope with risks and uncertainties are expected to venture and to exploit the advantages and opportunities that might rise from the enlargement with anticipation. In addition, benefits and advantages of locating at the strategically critical location, like the CEECs, prior to the entrance of competitors may provide a significant and favorable position within the market. Thus, we considered that the FDI carried out before the actual enlargement as being anticipatory and motivated to exploit future opportunities and pre-empt competitors and further assumed that larger firms were involved with these FDI before 2004.

Based on these observations and assumptions, we established a hypothesis to test this dimension and carried out further analysis. We examined our research model by two different groups of firms divided by their size; larger firms and SMEs. The results demonstrated interesting facts; the increase of FDI inflows after the enlargement was primarily responsible by the SMEs, as larger firms have not contributed. This was the actual reason as to why the monetary FDI was insignificantly affected by the enlargement of the EU. The result that both the number and monetary amount of FDI of larger firms was not significantly influenced by the enlargement means that the actual effects of enlargement has been completely exhausted and were not considered to be a viable factor for FDI inflows, at least from a larger firm's point of view. Nevertheless, we may be able to suggest, based on the findings, that SMEs made their move when the enlargement was completed; it was the uncertainties and unknown risks that made them hesitate to invest before the enlargement; further, the characteristics of the subsequent FDI by SMEs, when significant risks and uncertainties were eliminated, may be generalized as risk aversion.

\section{Conclusion}

FDI in the CEECs was considered to be greater than one should expect, given the actual level of income, market size, proximity to western Europe, and the price of production factors, which implied the importance of the effect of enlargement (Brenton/Mauro 1999). It is widely accepted that the formation of a common economic region triggers FDI inflows (Dent 1997; Buckley et al. 2001). In fact, the actual FDI inflows to the CEECs showed a dramatic increase in the early 2000s, but it was much earlier than the actual enlargement realized by 2004 . This is why the previous studies suggested that the effects of enlargement on FDI flows would disappear after the actual enlargement (Egger/Pfaffer- 
mayr 2004). However, the inflows of Korean FDI had increased even after the actual enlargement. Based on this fact, this study attempted to identify how regional integration and spatial enlargement would affect the strategic decisions firms from outside of an integrated region and further explore a new dimension of this question, which was not addressed in previous studies.

This study evaluated the effects of the enlargement of the EU with the accession of 5 CEECs - the Czech Republic, Romania, Poland, Hungary and the Slovak Republic - on Korean FDI to these countries, via analyses of datasets collected between 2000 and 2007. The results showed a number of particular patterns of Korean FDI in the CEECs of before and after the actual enlargement and casual relations between the enlargement and Korean FDI flows. First, the number of new investments from Korea increased significantly after the enlargement, whereas the monetary amount of total investment did not change significantly. Other gravity factors derived from the market size thesis were not decisively influenced by the FDI flows. Second, an extended analysis of Korean FDI in 5 Western European countries demonstrated that FDI inflows to the CEECs after the enlargement were not at the expense of FDI inflows into Western Europe. This demonstrated that the enlargement of the EU exerted only minimal effects on FDI inflows into Western Europe. Third, the results from the analysis of complementarity between FDI and trade indicated that the CEECs' import from Korea has increased after the EU accession; however, there was no direct effect from the Korean FDI into the region.

Lastly, the subsequent analysis based on the initial finding that each Korean FDI after the enlargement was trivial revealed that the majority of investments after the enlargement were responsible by the SMEs. This disclosure implied that FDI carried out before the actual enlargement is anticipatory in nature when subsequent FDI after the enlargement are mainly to avert risks and uncertainties associated with the enlargement. Considering the size and capacity of those firms, it may have proven difficult for them to take risks in investing in the CEECs prior to the completion of the EU enlargement. Thus, we may conclude that whenever higher FDI flows are observed after the actual enlargement, such phenomena is mainly the result of firm motives to avert risks and uncertainties and other FDI prior to the completion of enlargement; after the announcement, the motives are to exploit opportunities and to pre-empt competitors with anticipatory motives.

This study provides theoretical understandings related to the regional economic agreement and FDI flows defined as anticipatory and risk averting subsequent FDI according to the size of firms as well as practical implications for both firms and policy makers interested in the managerial decision based on the spatial development of economic regionalism. A lack of accumulated data, however, prevented us from pursuing and examining the differences by industries and sectors, especially because Korean FDI has only recently begun in most of the CEECs. There is also a need to examine countries other than Korea which have 
increased their FDI after the enlargement in order to confirm the findings of this study, given the country specific differences.

\section{References}

Alguacil, M./Cuadros, A./Orts, V. (2008): EU Enlargement and Inward FDI, in: Review of Development Economics, 12, 3, 594-604.

Altomonte, C./Guagliano, C. (2003): Comparative Study of FDI in Central and Eastern Europe and the Mediterranean, Economic Systems, 27, 2, 223-246.

Balassa, B. (1961): The theory of economic integration. London: George Allen \& Unwin.

Baldwin, R.E./Francois, J.F./Portes, R. (1997): The costs and benefits of the eastern enlargement: the impact on the EU and central Europe, in: Economic Policy, 24, 2, 127-176.

Barrell, R./Holland, D. (2000): Foreign direct investment and enterprise restructuring in central Europe, in: Economics of Transition, 8, 2, 477-504.

Barry, F. (2002): EU accession and prospective FDI flows to CEE countries: a view from Ireland. Working paper, University College Dublin.

Bhagwati, J. (1983): International factor mobility: Essays in International Economic Theory. Cambridge, London: MIT Press.

Bevan, A. et al. (2001): The impact of EU accession prospects on FDI inflows to central and eastern Europe. Policy Paper 06/01, University of Sussex.

Bevan, A./Estrin, S. (2004): The determinants of foreign direct investment into European transition economies, in: Journal of Comparative Economics, 32, 4, 775-787.

Bhagwati, J. (1987): Quid pro quo foreign investment and welfare: a political-economy- theoretic model, in: Journal of Development Economics, 27, 1-2, 127-138.

Brenton, P./Di Mauro, F./Lücke, M. (1999): Economic integration and FDI: An empirical analysis of foreign investment in the EU and in central and eastern Europe, in: Empirica, 26, 2, 95-121.

Brainard, S.L. (1993): A simple theory of multinational corporations and trade with a tradeoff between proximity and concentration. National Bureau of Economic Research, Working paper, 4269.

Brenton, P./Di Mauro, F. (1999): The potential magnitude and impact of FDI flows to CEECs, in: Journal of Economic Integration, 14, 1, 59-74.

Brenton, P./Di Mauro, F./Lucke, M. (1999): Economic integration and FDI: an empirical analysis of foreign investment in the EU and in Central and Eastern Europe, in: Empirica, 26, 2, 95-121.

Buckley, P.J./Casson, M. (1981): The optimal timing of foreign direct investment, in: Economic Journal, 91, 361, 75-87.

Buckley, P.J./Clegg, J./Forsans, N. (2001): Increasing the size of the "country: regional economic integration and foreign direct investment in a globalised world economy, in: Management International Review, 41, 3, 251-274.

Buigues, P./Jacquemin, A. (1994): Foreign investment and exports to the European Community, in: Mason, M./Encarnation, D. (eds.) Does Ownership Matter?, Oxford: Clarendon Press. 
Bussière, M./Fidrmuc, J./Schnatz, B. (2008): EU Enlargement and Trade Integration: Lessons from a Gravity Model, in: Review of Development Economics, 12, 3, 562-576.

Carstensen, K./Toubal, F. (2004): Foreign direct investment in Central and Eastern European countries: a dynamic panel analysis, in: Journal of Comparative Economics, 32, 1, 322.

Cieslik, A./Ryan, M. (2004): Explaining Japanese direct investment flows into an enlarged Europe: A comparison of gravity and economic potential approaches, in: The Japanese and International Economies, 18, 1, 12-37.

Clegg, J. (1999): The determinants of new foreign direct investment capital flows into the European Community: a statistical comparison of the USA and Japan, in: Journal of Common Market Studies, 37, 4, 597-616.

Corden, W.M. (1972): Economies of scale and customs union theory, in: Journal of Political Economy, 80, 1, 465-75.

Dent, C.M. (1997): The European Economy: The global context. London: Routhledge.

Dunning, J.H. (1997): The European internal market programme and inbound foreign direct investment, in: Journal of Common Market Studies, 35, 2, 189-223.

Eckert, S./Rossmeissl, F. (2005): Consequences of convergence - western firms' FDI activities in central and eastern Europe at the dawning of EU-enlargement, in: Journal for East European Management Studies, 10, 1, 55-74.

Egger, P./Pfaffermayr, M. (2004): Foreign direct investment and European integration in the 1990s, in: The World Economy, 27, 1, 99-110.

European Commission (1997): Economies of Scale, The Single Market Review, Subseries V: Impact on competition and scale effects. Brussels: European Commission.

Freund, C./Djankov, S. (2000): Which Firms do Foreigners Buy?: Evidence from Korea. Policy Research Working Paper Series 2450, World Bank.

Galego, A./Vieira, C./Vieira, I. (2004): The CEEC as FDI attractors: a menace to the EU periphery?, in: Emerging Markets and Finance and Trade, 40, 5, 74-91.

Görg, H./Greenaway, D. (2003): Is there a potential for increase in FDI for Central and Eastern European Countries following EU accession?, in: Hermann, H./Lipsey, R.E. (eds.): Foreign direct investment in the real and financial sector of industrial countries, Berlin: Springer, 165-183.

Janicki, H.P./Wunnava, P.V. (2004): Determinants of foreign direct investment: empirical evidence from EU accession candidates, in: Applied Economics, 36, 5, 505-509.

Hirsch, S./Almor, T. (1995): Outsider's response to Europe 1992: theoretical considerations and empirical evidence, in: Journal of International Business Studies, 26, 2, 223-237.

Hyun, J.H. (2003): Korean automotive FDI in Europe: the effects of economic integration on motivation, pattern of FDI and industrial location. London: Palgrave.

Krugman, P. (1991): Increasing returns and economic geography, in: Journal of Political Economy, 99, 3, 483-499.

Kumar, N. (1998): Multinational enterprises, regional economic integration, and exportplatform production in the host countries: an empirical analysis for the US and Japanese corporations, in: Weltwirtschaftliches Archiv, 134, 3, 450-483. 
Lankes, H.-P./Venables, A.J. (1996): Foreign direct investment in economic transition: the changing pattern of investment, in: Economics of Transition, 4, 2, 331-347.

Larimo, J./Arslan, A. (2013) Determinants of foreign direct investment ownership mode choice: Evidence from Nordic investment in Central and Eastern Europe, in: Journal for East European Management Studies, 18, 2, 232-263.

Lansbury, M./Pain, N./Smidkova, K. (1996): Foreign direct investment in central Europe since 1990: an empirical study, in: National Institute Economic Review, 156, 104-113.

Lipsey, R.E./Weiss, M.Y. (1984): Foreign Production and Exports of Individual Firms, in: Review of Economics and Statistics, 66, 2, 304-307.

Lipsey, R.E./Weiss, M.Y. (1981): Foreign production and exports in manufacturing industries, in: Review of Economics and Statistics, 63, 4, 488-494.

Markusen, J. (1995): The boundaries of multinational enterprises and the theory of international, in: Journal of Economic Perspectives, 9, 2, 169-189.

Marques, H. (2008): Trade and factor flows in a diverse EU: what lessons for the eastern enlargement(s)?, in: Journal of Economic Surveys, 22, 2, 364-408.

Meyer, K. (2001): Institutions, transaction costs, and entry mode choice in Eastern Europe, in: Journal of International Business Studies, 32, 2, 357-367.

Meyer, K.E./Peng, M.W. (2005): Probing theoretically into Central and Eastern Europe: transactions, resources, and institutions, in: Journal of International Business Studies, $36,6,600-621$.

Ministry of Commerce, Industry \& Energy (2005): The strategy of expanding investment into Eastern Europe, Research Report.

Mundell, R.A. (1957): International trade and factor mobility, in: American Economic Review, 47, 3, 321-35.

Nielsen, J./Heinrich, H./Hansen, J. (1992): An economic analysis of the EC. Berkshire: McGraw-Hill.

Papazoglou, C./Pentecost, E./Marques, H. (2006): A gravity model forecast of the potential trade effects of the EU enlargement: Lessons from 2004 and path-dependency in integration, in: World Economy, 29, 8, 1077-89.

Pelkmans, J./Casey, J.-P. (2003): EU enlargement: External economic implications, in: Intereconomics, 38, 4, 196-209.

Resmini, L. (2000): The determinants of foreign direct investment in the CEEs - new evidence from sectorial patterns, in: Economics of Transition, 8, 3, 665-689.

Rugman, A.M. (1990): Multinationals and Canada-United States Free Trade. Columbia: University of South Carolina Press.

Rutkowski, A. (2006): Inward FDI, skilled labour, and product differentiation in the CEEC, in: Journal for East European Management Studies, 11, 2, 91-112.

Sachwald, F. (2003): FDI and the economic status of Korea: The hub strategy in perspective. Washington D.C.: Korean Economic Institute.

Scaperlanda, A./Mauer, L. (1969): Determinants of US direct investment in the EEC, in: American Economic Review, 59, 3, 558-68. 
Scaperlanda, A.E./Mauer, L.J. (1973): The impact of controls on United States direct foreign investment in the European economic community, in: Southern Economic Journal, 39, $3,419-423$.

Skinner, H./Kubacki, K./Moss, G./Chelly, D. (2008): International marketing in an enlarged European Union: Some insights into cultural heterogeneity in Central Europe, in: Journal for East European Management Studies, 13, 3, 193-215.

Tintin, C. (2013): The determinants of foreign direct investment inflows in the Central and Eastern European Countries: The importance of institutions, in: Communist and PostCommunist Studies, 46, 2, 287-298.

UNCTAD (1996): Foreign direct investment and trade: Interlinkage and policy implications, World Investment Report 1996. Geneva, New York: United Nations.

UNCTC (1990): Regional Economic Integration and Transnational Corporations in the 1990s: Europe 1992, North America, and Developing Countries. New York: United Nations.

UNCTC (1994): World Investment Report 1994: Transnational Corporations, Employment and the Workplace. New York: United Nations.

Vavilov, S. (2005): Trade and FDI in Petroleum Exporting Countries: Compliments or Substitutes? Working paper, Université Paris Panthéon-Sorbonne-Economie, http:// sugarhoover.co.uk/articulosrecibidos/Vavilov.pdf.

Viner, J. (1950): The Customs Union Issue. London: Stevens

Yannopoulos, G.N. (1990): Foreign direct investment and European integration; the evidence from the formative years of the European Community, in: Journal of Common Market Studies, 28, 4, 235-57. 